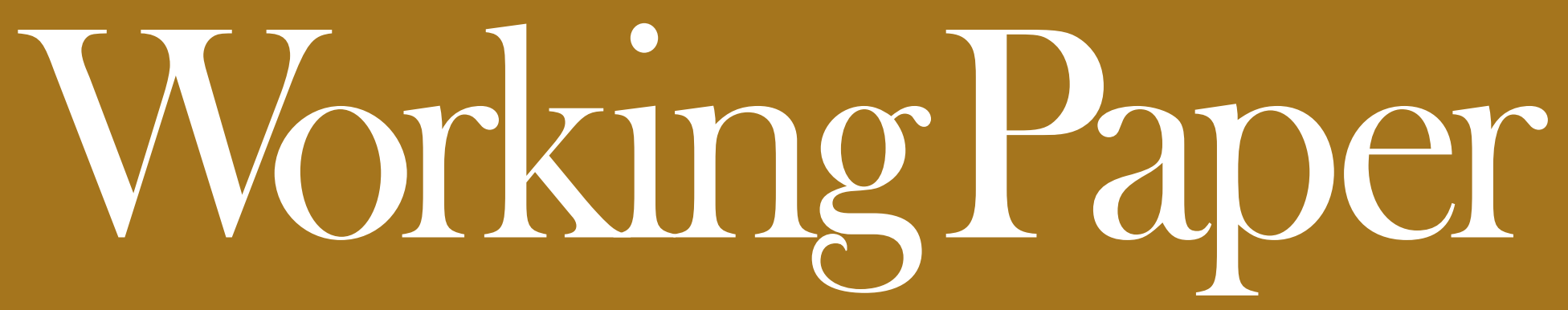

No. 130. September 2013

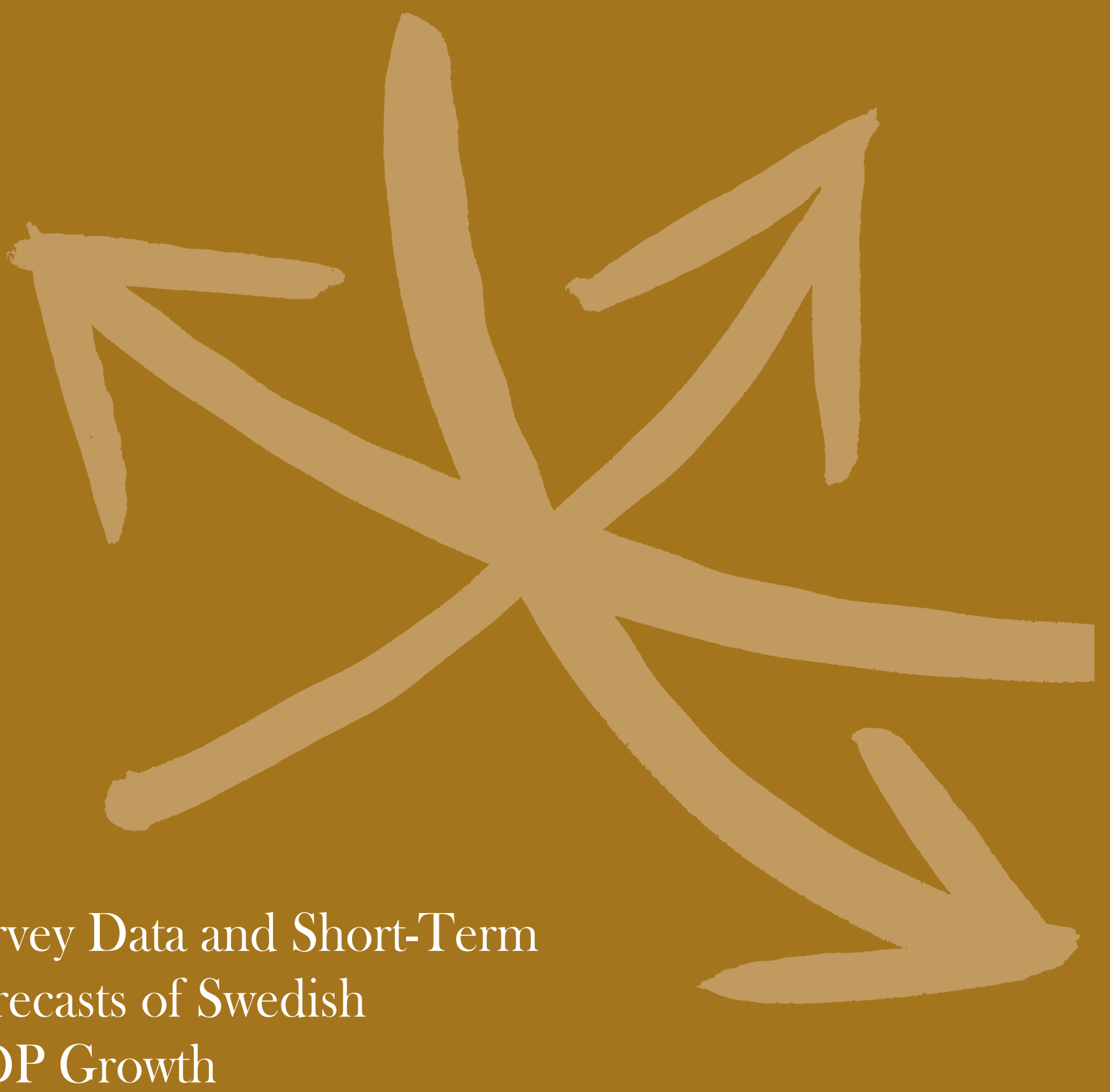

By Pär Österholm

National Institute of Economic Research

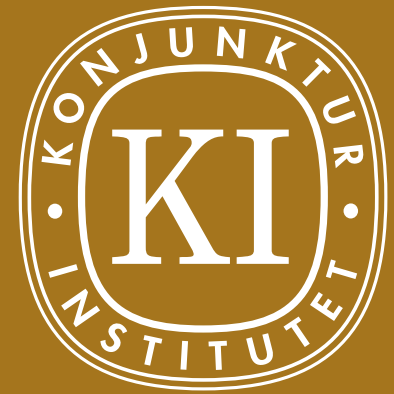





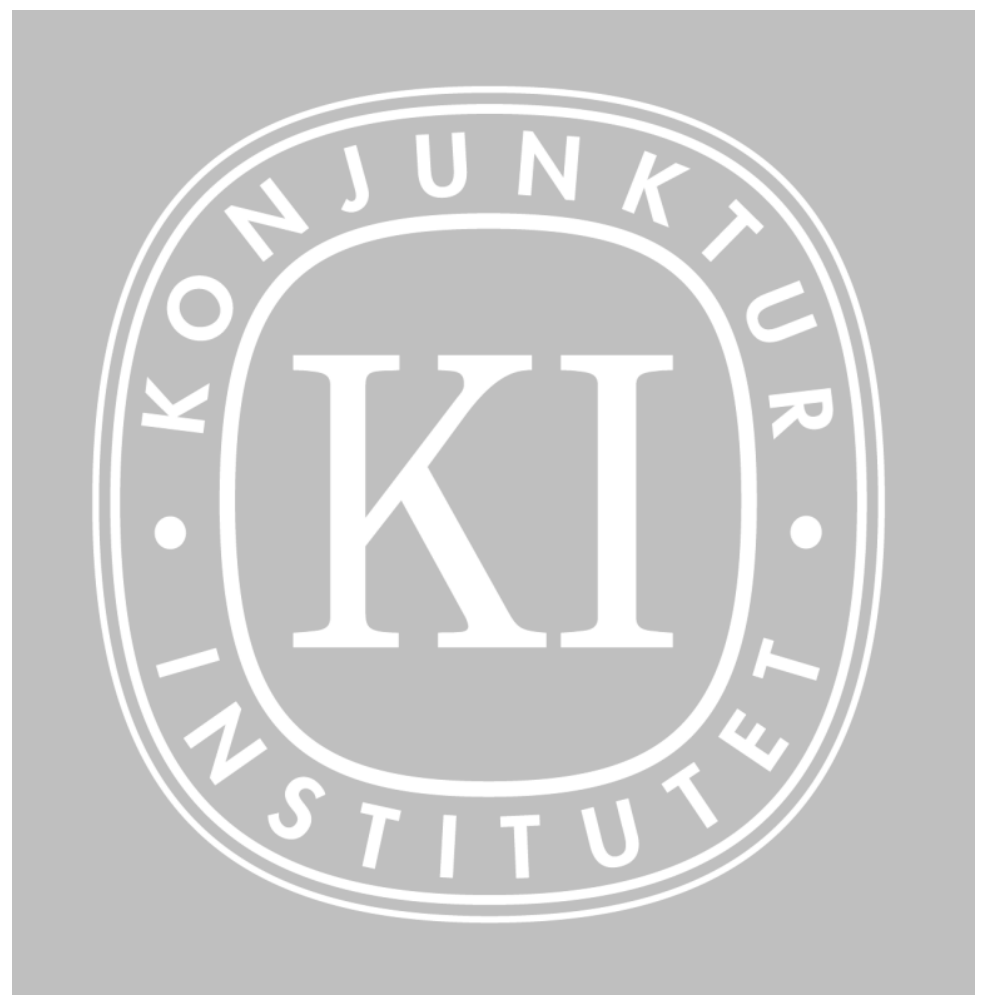

\section{Survey Data and Short-Term Forecasts of Swedish GDP Growth}

Pär Österholm

September, 2013 
NIER prepares analyses and forecasts of the Swedish and international economy and conducts related research. NIER is a government agency accountable to the Ministry of Finance and is financed largely by Swedish government funds. Like other government agencies, NIER has an independent status and is responsible for the assessments that it publishes.

The Working Paper series consists of publications of research reports and other detailed analyses. The reports may concern macroeconomic issues related to the forecasts of the institute, research in environmental economics, or problems of economic and statistical methods. Some of these reports are published in their final form in this series, whereas others are previews of articles that are subsequently published in international scholarly journals under the heading of Reprints. Reports in both of these series can be ordered free of charge. Most publications can also be downloaded directly from the NIER website: www.konj.se. 


\begin{abstract}
In this paper, we evaluate forecasting models for Swedish GDP growth which make use of data from Sweden's most important business survey, the Economic Tendency Survey. Employing nine years of quarterly real-time data, we conduct an out-of-sample forecast exercise. Results indicate that the survey data have informational value that can be used to improve forecasts, thereby confirming the empirical relevance of survey data for GDP forecasters.
\end{abstract}

JEL Classification: E22, E27

Keywords: Out-of-sample forecasts, Real-time data 


\section{Summary in Swedish}

I denna studie utvärderas prognosmodeller för svensk BNP-tillväxt som utnyttjar data från Konjunkturbarometern. Resultaten från en prognosövning baserad på nio års realtidsdata ger vid handen att data från Konjunkturbarometern kan användas för att förbättra prognoser. Dessa resultat bekräftar att det är empiriskt relevant för prognosmakare att beakta enkätdata när BNP-tillväxten skall prognostiseras. 


\section{Contents}

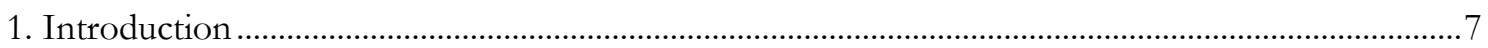

2. Empirical study

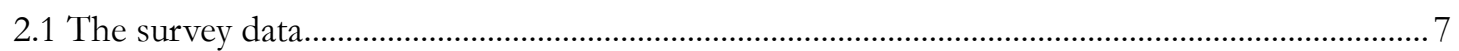

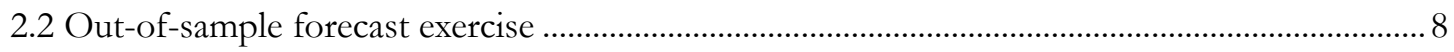

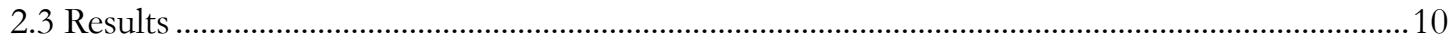

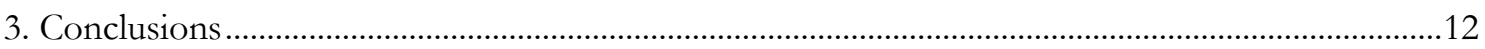

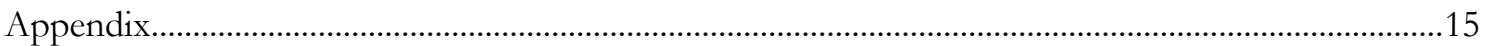





\section{Introduction}

Knowing at which rate the economy is expanding or contracting is of fundamental importance to many agents in the economy. There is accordingly widespread interest among economists and forecasters to predict GDP growth. One problem when forecasting GDP growth though is that the time series in most countries is weakly serially correlated; this means that traditional univariate ARIMA models tend to not be very useful tools for this purpose. It should hence be beneficial to turn to alternative forecasting models. When it comes to short-run forecasts, one reasonable alternative is to rely on models that employ survey data, where these data are supposed to serve as coinciding or leading indicators; see, for example, Mitchell (2009) and Banbura and Rünstler (2011). ${ }^{1}$

The purpose of this paper is to assess if short-term forecasts of Swedish GDP growth can be improved by using survey data provided in the National Institute of Economic Research's Economic Tendency Survey and, if so, which variables are most useful. This is done by conducting a simulated out-of-sample forecast exercise where simple univariate regression models are evaluated using nine years of quarterly real-time data. ${ }^{2}$ Our results indicate that there are improvements to be made from using the survey data, even if the usefulness of different variables seems to vary substantially.

\section{Empirical study}

\subsection{The survey data}

The National Institute of Economic Research's Economic Tendency Survey is the largest survey of its kind in Sweden. More than 6000 companies are included in the survey and each month representatives from upper management of the companies are asked questions concerning the present situation and the outlook for the near future regarding, for example, output, new orders, employment and prices. ${ }^{3}$ However, the extent of the survey differs somewhat over time; a larger number of questions is asked in January, April, July and October. In this paper, we rely on the data from these more extensive surveys and hence work purely on a quarterly frequency. ${ }^{4}$

The data from the Economic Tendency Survey are aggregated in different ways for presentational purposes. There are four main categories: manufacturing industry, construction industry, retail trade

\footnotetext{
1 Additional studies on the relationship between survey data and the real economy include Carroll et al. (1994), Ludvigson (2004), Dreger and Schumacher (2005), Mitchell et al. (2005), Kwan and Cotsomitis (2006) and Siliverstovs (2013). Alternatively, one could consider using financial data to forecast the real economy; see, for example, Mody and Taylor (2003).

2 For discussions concerning the importance of using real-time data, see, for example, Croushore and Stark (2001).

3 The questionnaires employed in the survey can be found at http://www.konj.se/1666.html. These show exactly how the question underlying each variable employed in the empirical analysis in this paper is phrased.

${ }^{4}$ As an alternative, one could consider working with mixed frequencies; see, for example, Armesto et al. (2010) for a discussion.
} 
and private service sector. These four main categories are in turn divided into sub-categories. ${ }^{5}$ In this paper, we use a subset of the data which is judged to be the most relevant while at the same time meeting a requirement of the time series being long enough. To be specific, we employ data for the manufacturing industry, the investment goods industry, the construction industry and the total business sector.

To simplify the analysis of the data, the concept "net figures" is employed, where a net figure is the difference between the percentage of respondents reporting an increase and a decrease for a certain question. For example, if 45 percent of respondents state that there has been an increase in output volume over the past three months, 25 percent that there has been no change and 30 percent that there has been a decrease, the net figure is $45-30=15 . .^{\text {In }}$ total, 77 variables from the Economic Tendency Survey are employed in this paper; see Table 1 in the appendix for a complete list.

\subsection{Out-of-sample forecast exercise}

The out-of-sample forecast exercise is conducted using quarterly real-time data of seasonally adjusted GDP. The time series with net figures from the Economic Tendency Survey are not adjusted in any way and the most recent vintage is hence equivalent to real-time data.

We evaluate a short-term forecast of GDP growth. To be specific, we are interested in forecasting quarter $t+i$ GDP growth when standing part way through quarter $t+i$. This can be seen as conducting a nowcast. Alternatively, it could - since the national accounts are released with a delay of approximately two months - also be seen as having a forecast horizon of roughly one quarter. ${ }^{7}$

The benchmark model in our out-of-sample forecast exercise is an AR(1) model,

$$
g_{t}=\delta+\rho g_{t-1}+v_{t},
$$

where $g_{t}$ is quarterly GDP growth and $v_{t}$ is an error term. ${ }^{8}$ However, Swedish GDP growth is very weakly serially correlated and a model with only a constant term therefore also appears to be a reasonable choice. ${ }^{9}$ We accordingly also estimate

\footnotetext{
${ }^{5}$ For a general description of the survey, see http://www.konj.se/1670.html.

${ }^{6}$ This way of summarising the data is common practice in the literature; see, for example, Carabenciov et al. (2008).

${ }^{7}$ For a discussion of the importance of good nowcast/short-term forecasts, see, for example, Banbura et al. (2011).

8 The AR(1) model is a commonly used benchmark in the macroeconomic forecasting literature due to its simplicity, flexibility and a forecasting performance which typically tends to be decent; see, for example, Mitchell (2009) and Pesaran et al. (2009).
} 
$g_{t}=\kappa+\chi_{t}$,

where $\chi_{t}$ is an error term. Finally, we estimate 77 models with survey data. These are given by

$g_{t}=\alpha_{j}+\beta_{j} S_{j, t}+\varepsilon_{j, t}$,

where $\varepsilon_{j, t}$ is the error term for model $j$ and $S_{j, t}$ is a variable based on the survey data, $j=1, \ldots, 77$.

Figure 1. GDP growth.

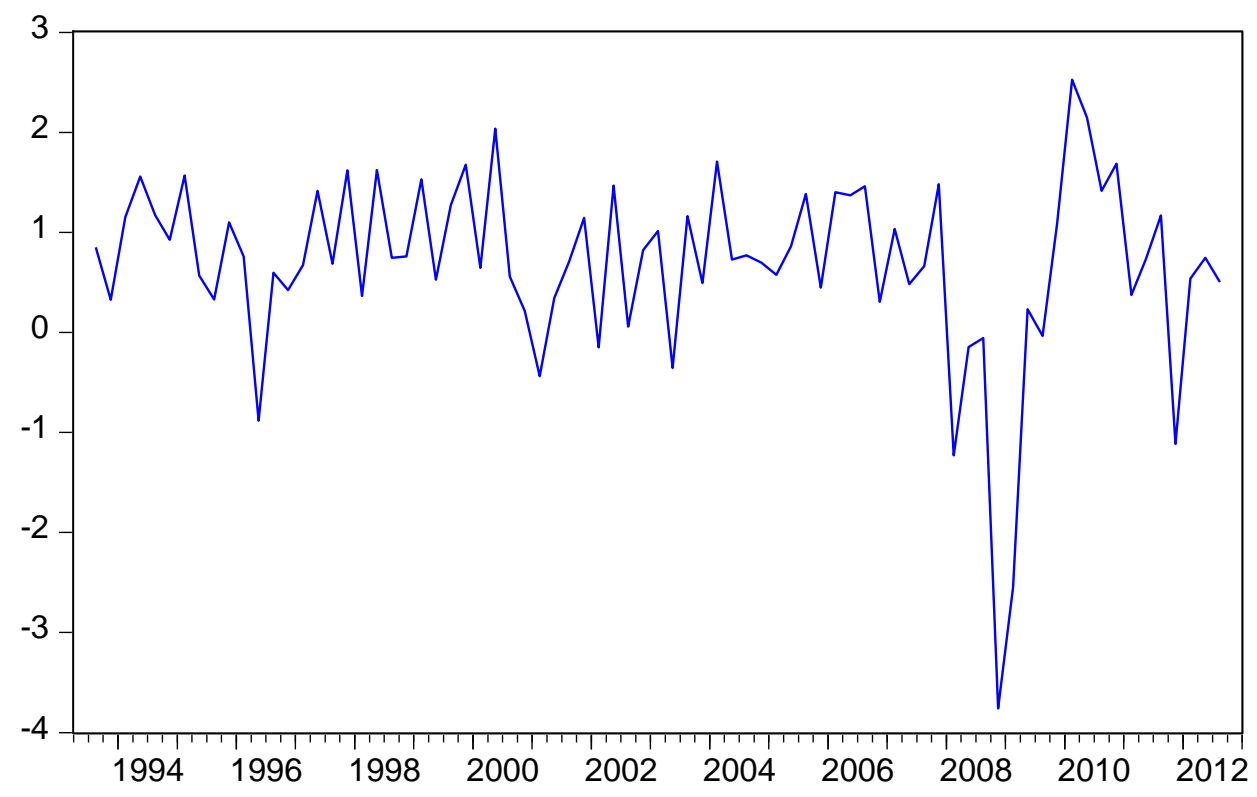

Note: Percentage change from previous quarter in seasonally adjusted GDP. Vintage of data published in November 2012.

The first out-of-sample forecast is made using data on GDP growth from 1993Q2 until 2003Q4.10,11 The forecast generated from this estimation is accordingly for 2004Q1. We then extend the sample one period, re-estimate the models and generate new forecasts, this time for 2004Q2. The last forecast uses data on GDP growth until 2012Q2 and the forecast is made for 2012Q3. This yields a total of 35 out-of-sample forecasts to evaluate for each of the 79 models.

9 The weak serial correlation is visually confirmed in Figure 1. In real time, standing at the point in time of the first forecast, GDP growth would actually have been judged a white noise process according to the autocorrelation and partial autocorrelation functions. (These are not reported but are available upon request.)

10 This means that the earliest point in time at which it could have been made was late February/early March 2004.

11 Some models are estimated on a shorter sample, starting in 1996Q2, since some of the survey data series are not available from 1993. 
Forecast errors are recorded and used to calculate the root mean square forecast errors (RMSFEs).

The RMSFE is defined as

$R M S F E=\sqrt{\frac{1}{N} \sum_{i=0}^{N-1}\left(g_{t+i}-g_{t+i \mid t+i}\right)^{2}}$,

where $N$ is the number of forecasts (that is, 35), $g_{t+i}$ is the outcome at time $t+i$ and $g_{t+i \mid t+i}$ is the forecast of GDP growth for quarter $t+i$ made earlier the same quarter. ${ }^{12}$

\subsection{Results}

The results from the out-of-sample forecast exercise are given in Table 1 in the appendix. As can be seen, the benchmark AR(1) model has an RMSFE of 0.900. The forecasting performance of the model with only a constant is almost identical, 0.905 .

Among the models employing survey data, the forecasting performance varies substantially. The lowest RMSFE is found for the model which makes use of the survey data describing the outcome for the export orders in the manufacturing industry (question 108 in the Economic Tendency Survey); the time series is plotted together with GDP growth in Figure 2. The RMSFE of this model is 0.739 which is 18 percent lower than that of the $\mathrm{AR}(1)$ model; this constitutes a fairly large improvement in forecasting performance. It can be noted that the model relying on the data based on this question for the investment goods industry also generates good out-of-sample forecasts. In a similar manner, the outcome for the domestic orders (question 107) and expectations concerning new orders in the domestic (question 205) and foreign (question 206) markets generally appear useful from a forecasting perspective. Data based on quite a few questions do not appear useful though. One of the least informative questions for GDP growth appears to be the outcome concerning finished inventories (question 121). Both models relying on these data have RMSFEs that are larger than that of the $\operatorname{AR}(1)$ model $(0.968$ for the manufacturing industry and 0.959 for the investment goods industry).

\footnotetext{
12 No tests for whether differences in forecasting performance are statistically significant are conducted. Significance testing using, for example, tests in the style of Diebold and Mariano (1995) - is, in our opinion, not particularly interesting in the present application. In line with, for example, Beechey and Österholm (2010) we argue that the model which minimises the loss function of the forecaster (which here is assumed to be quadratic) should be the preferred one. For further criticism of significance testing, see Armstrong (2007).
} 
Figure 2. GDP growth and export orders in the manufacturing industry.

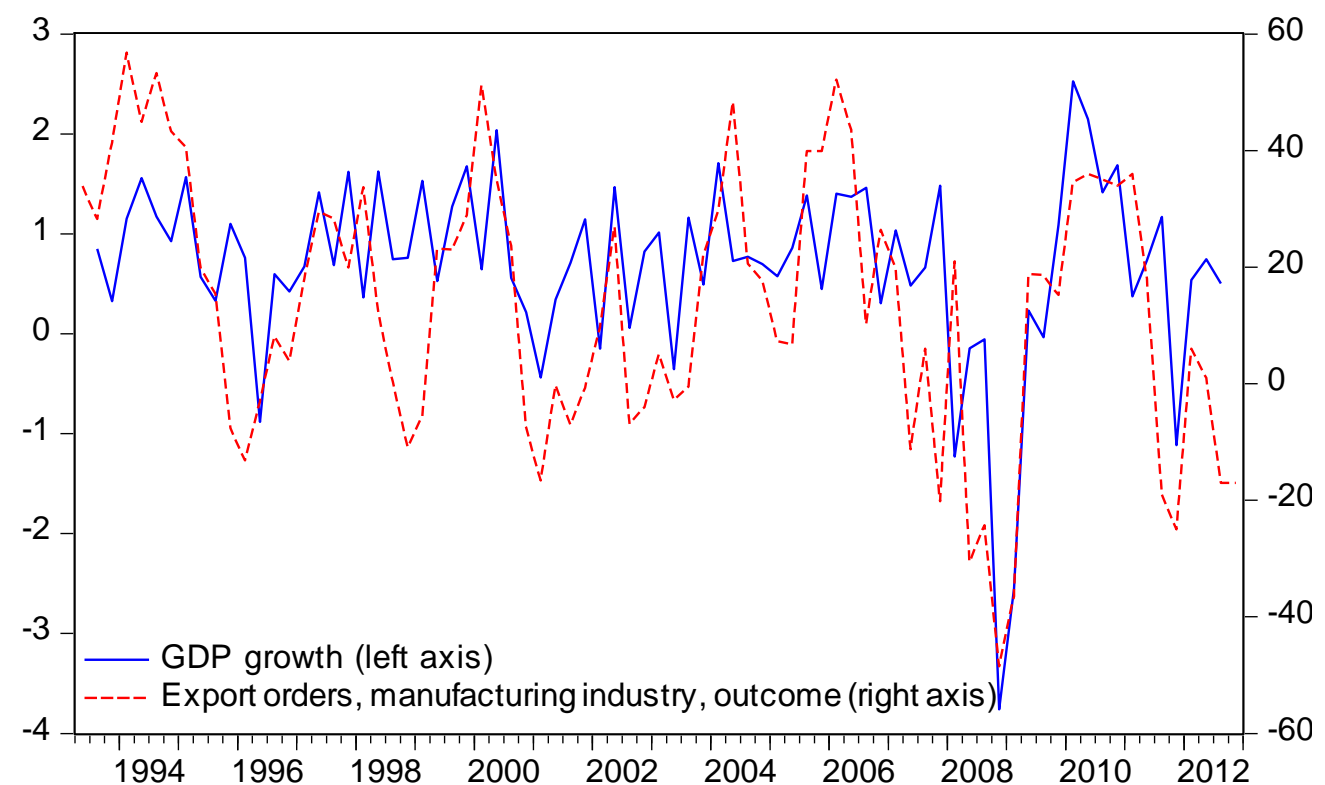

Note: GDP growth is measured as the percentage change from the previous quarter in seasonally adjusted GDP. Vintage of data published in November 2012. The outcome for the export orders in the manufacturing industry is measured as the net figure.

As is well-known from the forecasting literature, an arithmetic mean of available forecasts often performs well; see, for example, Clemen (1989). In order to assess whether such a strategy would pay off also in this case, we evaluate the forecast which at each point in time is generated as the arithmetic mean of the forecasts from every model excluding the $\mathrm{AR}(1)$ model. As it turns out, this forecast has an RMSFE which is only marginally lower than that of the AR(1) model. This finding is perhaps not too surprising given that we just established that several questions were associated with poor forecasting performance. It hence does not seem like a very appealing strategy for a forecaster to rely on this mean forecast when forecasting Swedish GDP growth in practice.

Based on the findings so far in this paper though, one could argue that it is would be a reasonable approach in practice to choose a subset of the models - say the ten best - and use the mean of those as one's point forecast. ${ }^{13}$ Evaluating this strategy, we find that such a forecast would have had an RMSFE of 0.752 - substantially lower than the AR(1) model's and second only to the best model described above. The difference relative to the best model is negligible in practice though. It should be pointed out that this forecast could not have been generated in real time since we then did not know which variables would be most successful in predicting GDP growth in this sample. However, from a practical viewpoint, it seems reasonable to expect this forecast to do well in the future.

13 Specifically, the best ten models are those relying on data from questions 107, 108, 205 and 206 for the manufacturing industry, questions 107, 108, 201, 205 and 206 for the investments goods industry and question 205 for the construction industry; see Table 1 in the appendix for details. 


\section{Conclusions}

In this paper, we have investigated whether short-term forecasts of GDP growth in Sweden can be improved by relying on survey data. Our results indicate that the survey data have informational value that can be used to improve the forecasts. ${ }^{14}$ When forecasting Swedish GDP growth in practice, a forecast based on the simple arithmetic mean of the forecasts from the best performing models should be a reasonable approach.

14 Other studies that have found that the Economic Tendency Survey has had predictive power for real economic variables in Sweden include Hansson et al. (2005) and Österholm (2010). Neither of these studies used real-time data though. 


\section{References}

Armesto, M. T., Engemann, K. M. and Owyang, M. T. (2010), "Forecasting with Mixed Frequencies", Federal Reserve Bank of St Louis Review 92, 521-536.

Armstrong, J. S. (2007), "Significance Tests Harm Progress in Forecasting", International Journal of Forecasting 23, 321-327.

Banbura, M. and Rünstler, G. (2011), "A Look into the Factor Model Black Box: Publication Lags and the Role of Hard and Soft Data in Forecasting GDP", International Journal of Forecasting 27, 333-346.

Banbura, M., Giannone, D. and Reichlin, L. (2011), “Nowcasting”, in Clements, M. P. and Hendry, D. F. (eds), The Oxford Handbook of Economic Forecasting. Oxford University Press, New York.

Beechey, M. and Österholm, P. (2010), "Forecasting Inflation in an Inflation Targeting Regime: A Role for Informative Steady-State Priors", International Journal of Forecasting 26, 248-264.

Carabenciov, I., Ermolaev, I., Freedman, C., Juillard, M., Kamenik, O., Korshunov, D., Laxton, D. and Laxton, J. (2008), "A Small Quaterly Multi-Country Projection Model with FinancialReal Linkages and Oil Prices”, IMF Working Paper 08/280, International Monetary Fund.

Carroll, C. D., Fuhrer, J. C. and Wilcox, D. W. (1994), "Does Consumer Sentiment Forecast Household Spending? If So, Why?”, American Economic Review 84, 1397-1408.

Clemen, R. T. (1989), "Combining Forecasts: A Review and Annotated Bibliography”, International Journal of Forecasting 5, 559-583.

Diebold, F. X. and Marino, R. S. (1995), "Comparing Predictive Accuracy”, Journal of Business and Economic Statistics 13, 253-263.

Dreger, C. and Schumacher, C. (2005), "Out-of-sample Performance of Leading Indicators for the German Business Cycle: Single vs. Combined Forecasts", Journal of Business Cycle Measurement and Analysis 2005/1, 71-87.

Croushore, D. and Stark, T. (2001), “A Real-Time Data Set for Macroeconomists”, Journal of Econometrics 105, 111-130.

Hansson, J., Jansson, P. and Löf, M. (2005), "Business Survey Data: Do They Help in Forecasting GDP Growth?” International Journal of Forecasting 21, 377-389.

Kwan, A. C. C. and Cotsomitis, J. A. (2006), "The Usefulness of Consumer Confidence in Forecasting Household Spending in Canada: A National and Regional Analysis", Economic Inquiry 44, 185-197.

Ludvigson, S. (2004), "Consumer Confidence and Consumer Spending", Journal of Economic Perspectives 18, 29-50. 
Mitchell, J. (2009), "Where Are We Now? The UK Recession and Nowcasting GDP Growth Using Statistical Models", National Institute Economic Review 209, 60-69.

Mitchell, J., Smith, R. J. and Weale, M. (2005), "Forecasting Manufacturing Output Growth Using Firm-Level Survey Data", Manchester School 73, 479-499.

Mody, A. and Taylor, M. P. (2003), "The High-Yield Spread as a Predictor of Real Economic Activity: Evidence of a Financial Accelerator for the United States”, IMF Staff Papers 50, 373402.

Österholm, P. (2010), "Improving Unemployment Rate Forecasts Using Survey Data", Finnish Economic Papers 23, 16-26.

Pesaran, M. H., Schuermann, T. and Smith, L. V. (2009), "Forecasting Economic and Financial Variables with Global VARs", International Journal of Forecasting 25, 642-675.

Siliverstovs, B. (2013), "Do Business Tendency Surveys Help in Forecasting Employment? A RealTime Evidence for Switzerland", Journal of Business Cycle Measurement and Analysis 2013/1, 120. 


\section{Appendix}

Table 1. Root mean square forecast errors.

\begin{tabular}{|c|c|c|c|c|c|}
\hline & & $\begin{array}{l}\text { Equation ( } 3 \text { ): } \\
\text { Manufacturing }\end{array}$ & $\begin{array}{l}\text { Equation ( } 3 \text { ): } \\
\text { Investment }\end{array}$ & $\begin{array}{l}\text { Equation ( } 3 \text { ): } \\
\text { Construction }\end{array}$ & $\begin{array}{c}\text { Equation ( } 3 \text { ): } \\
\text { Total }\end{array}$ \\
\hline Equation 1: $\mathrm{AR}(1)$ & 0.900 & - & - & - & - \\
\hline Equation 2: Constant & 0.905 & - & - & - & - \\
\hline 101 & - & 0.826 & 0.855 & 0.889 & - \\
\hline 102 & - & 0.948 & 0.906 & 0.899 & - \\
\hline 103 & - & 0.910 & 0.889 & 0.899 & - \\
\hline 104 & - & 0.927 & 0.946 & 0.904 & - \\
\hline 105 & - & 0.931 & 0.915 & 1.033 & - \\
\hline 106 & - & 0.891 & 0.909 & 0.911 & - \\
\hline 107 & - & 0.752 & 0.771 & - & - \\
\hline 1073 & - & - & - & 0.913 & \\
\hline 108 & - & 0.739 & 0.755 & - & - \\
\hline 109 & - & 0.887 & 0.905 & - & - \\
\hline 110 & - & 0.890 & 0.902 & - & - \\
\hline 112 & - & 0.908 & 0.939 & - & - \\
\hline 113 & - & 0.945 & 0.911 & - & - \\
\hline 114 & - & 0.926 & 0.898 & - & - \\
\hline 115 & - & 0.930 & 0.935 & - & - \\
\hline 116 & - & 0.882 & 0.907 & - & - \\
\hline 117 & - & 0.905 & 0.912 & - & - \\
\hline 118 & - & 0.914 & 0.914 & - & - \\
\hline 119 & - & 0.916 & 0.883 & - & - \\
\hline 120 & - & 0.890 & 0.879 & - & - \\
\hline 121 & - & 0.968 & 0.959 & - & - \\
\hline 122 & - & 0.856 & 0.878 & - & - \\
\hline 125 & - & 0.895 & 0.916 & - & - \\
\hline 201 & - & 0.820 & 0.816 & 0.845 & - \\
\hline 202 & - & 0.875 & 0.862 & 0.836 & - \\
\hline 203 & - & 0.927 & 0.910 & 0.833 & - \\
\hline 204 & - & 0.883 & 0.909 & 0.885 & - \\
\hline 205 & - & 0.804 & 0.777 & 0.787 & - \\
\hline 206 & - & 0.814 & 0.756 & - & - \\
\hline 207 & - & 0.818 & 0.856 & - & - \\
\hline Sales prices, present & - & - & - & - & 0.927 \\
\hline Sales prices, expectation & - & - & - & - & 0.913 \\
\hline Number of employees, present & - & - & - & - & 0.891 \\
\hline Number of employees, expectation & - & - & - & - & 0.832 \\
\hline Demand situation & - & - & - & - & 0.903 \\
\hline Shortage of labour & - & - & - & - & 0.914 \\
\hline $\begin{array}{l}\text { Main factor currently limiting } \\
\text { production: insufficient demand }\end{array}$ & - & - & - & - & 0.922 \\
\hline Mean (all) & 0.864 & - & - & - & - \\
\hline Mean (best ten) & 0.752 & - & - & - & - \\
\hline
\end{tabular}

Note: The numbers in the far left column refer to the number a specific quesiton has in the Economic Tencency Survey. 


\section{Titles in the Working Paper Series}

\begin{tabular}{|c|c|c|c|}
\hline No & Author & Title & Year \\
\hline 1 & $\begin{array}{l}\text { Warne, Anders and } \\
\text { Anders Vredin }\end{array}$ & $\begin{array}{l}\text { Current Account and Business Cycles: Stylized Facts } \\
\text { for Sweden }\end{array}$ & 1989 \\
\hline 2 & Östblom, Göran & $\begin{array}{l}\text { Change in Technical Structure of the Swedish } \\
\text { Economy }\end{array}$ & 1989 \\
\hline 3 & Söderling, Paul & $\begin{array}{l}\text { Mamtax. A Dynamic CGE Model for Tax Reform } \\
\text { Simulations }\end{array}$ & 1989 \\
\hline 4 & $\begin{array}{l}\text { Kanis, Alfred and } \\
\text { Aleksander Markowski }\end{array}$ & $\begin{array}{l}\text { The Supply Side of the Econometric Model of the } \\
\text { NIER }\end{array}$ & 1990 \\
\hline 5 & Berg, Lennart & The Financial Sector in the SNEPQ Model & 1991 \\
\hline 6 & $\begin{array}{l}\text { Ågren, Anders and Bo } \\
\text { Jonsson }\end{array}$ & $\begin{array}{l}\text { Consumer Attitudes, Buying Intentions and } \\
\text { Consumption Expenditures. An Analysis of the } \\
\text { Swedish Household Survey Data }\end{array}$ & 1991 \\
\hline 7 & $\begin{array}{l}\text { Berg, Lennart and } \\
\text { Reinhold Bergström }\end{array}$ & $\begin{array}{l}\text { A Quarterly Consumption Function for Sweden 1979- } \\
1989\end{array}$ & 1991 \\
\hline 8 & Öller, Lars-Erik & $\begin{array}{l}\text { Good Business Cycle Forecasts - A Must for } \\
\text { Stabilization Policies }\end{array}$ & 1992 \\
\hline 9 & $\begin{array}{l}\text { Jonsson, Bo and } \\
\text { Anders Ågren }\end{array}$ & $\begin{array}{l}\text { Forecasting Car Expenditures Using Household } \\
\text { Survey Data }\end{array}$ & 1992 \\
\hline 10 & $\begin{array}{l}\text { Löfgren, Karl-Gustaf, } \\
\text { Bo Ranneby and Sara } \\
\text { Sjöstedt }\end{array}$ & $\begin{array}{l}\text { Forecasting the Business Cycle Not Using Minimum } \\
\text { Autocorrelation Factors }\end{array}$ & 1992 \\
\hline 11 & Gerlach, Stefan & $\begin{array}{l}\text { Current Quarter Forecasts of Swedish GNP Using } \\
\text { Monthly Variables }\end{array}$ & 1992 \\
\hline 12 & Bergström, Reinhold & $\begin{array}{l}\text { The Relationship Between Manufacturing Production } \\
\text { and Different Business Survey Series in Sweden }\end{array}$ & 1992 \\
\hline 13 & $\begin{array}{l}\text { Edlund, Per-Olov and } \\
\text { Sune Karlsson }\end{array}$ & $\begin{array}{l}\text { Forecasting the Swedish Unemployment Rate: VAR } \\
\text { vs. Transfer Function Modelling }\end{array}$ & 1992 \\
\hline 14 & $\begin{array}{l}\text { Rahiala, Markku and } \\
\text { Timo Teräsvirta }\end{array}$ & $\begin{array}{l}\text { Business Survey Data in Forecasting the Output of } \\
\text { Swedish and Finnish Metal and Engineering } \\
\text { Industries: A Kalman Filter Approach }\end{array}$ & 1992 \\
\hline 15 & $\begin{array}{l}\text { Christofferson, } \\
\text { Anders, Roland } \\
\text { Roberts and Ulla } \\
\text { Eriksson }\end{array}$ & $\begin{array}{l}\text { The Relationship Between Manufacturing and Various } \\
\text { BTS Series in Sweden Illuminated by Frequency and } \\
\text { Complex Demodulate Methods }\end{array}$ & 1992 \\
\hline 16 & Jonsson, Bo & $\begin{array}{l}\text { Sample Based Proportions as Values on an } \\
\text { Independent Variable in a Regression Model }\end{array}$ & 1992 \\
\hline 17 & Öller, Lars-Erik & $\begin{array}{l}\text { Eliciting Turning Point Warnings from Business } \\
\text { Surveys }\end{array}$ & 1992 \\
\hline 18 & Forster, Margaret M & $\begin{array}{l}\text { Volatility, Trading Mechanisms and International } \\
\text { Cross-Listing }\end{array}$ & 1992 \\
\hline 19 & Jonsson, Bo & $\begin{array}{l}\text { Prediction with a Linear Regression Model and Errors } \\
\text { in a Regressor }\end{array}$ & 1992 \\
\hline
\end{tabular}




\begin{tabular}{|c|c|c|c|}
\hline 20 & $\begin{array}{l}\text { Gorton, Gary and } \\
\text { Richard Rosen }\end{array}$ & $\begin{array}{l}\text { Corporate Control, Portfolio Choice, and the Decline } \\
\text { of Banking }\end{array}$ & 1993 \\
\hline 21 & $\begin{array}{l}\text { Gustafsson, Claes- } \\
\text { Håkan and Åke } \\
\text { Holmén }\end{array}$ & $\begin{array}{l}\text { The Index of Industrial Production - A Formal } \\
\text { Description of the Process Behind it }\end{array}$ & 1993 \\
\hline 22 & Karlsson, Tohmas & $\begin{array}{l}\text { A General Equilibrium Analysis of the Swedish Tax } \\
\text { Reforms 1989-1991 }\end{array}$ & 1993 \\
\hline 23 & Jonsson, Bo & $\begin{array}{l}\text { Forecasting Car Expenditures Using Household } \\
\text { Survey Data- A Comparison of Different Predictors }\end{array}$ & 1993 \\
\hline 24 & $\begin{array}{l}\text { Gennotte, Gerard and } \\
\text { Hayne Leland }\end{array}$ & Low Margins, Derivative Securitites and Volatility & 1993 \\
\hline 25 & $\begin{array}{l}\text { Boot, Arnoud W.A. } \\
\text { and Stuart I. } \\
\text { Greenbaum }\end{array}$ & Discretion in the Regulation of U.S. Banking & 1993 \\
\hline 26 & $\begin{array}{l}\text { Spiegel, Matthew and } \\
\text { Deane J. Seppi }\end{array}$ & $\begin{array}{l}\text { Does Round-the-Clock Trading Result in Pareto } \\
\text { Improvements? }\end{array}$ & 1993 \\
\hline 27 & Seppi, Deane J. & $\begin{array}{l}\text { How Important are Block Trades in the Price } \\
\text { Discovery Process? }\end{array}$ & 1993 \\
\hline 28 & Glosten, Lawrence R. & Equilibrium in an Electronic Open Limit Order Book & 1993 \\
\hline 29 & $\begin{array}{l}\text { Boot, Arnoud W.A., } \\
\text { Stuart I Greenbaum } \\
\text { and Anjan V. Thakor }\end{array}$ & Reputation and Discretion in Financial Contracting & 1993 \\
\hline $30 \mathrm{a}$ & Bergström, Reinhold & $\begin{array}{l}\text { The Full Tricotomous Scale Compared with Net } \\
\text { Balances in Qualitative Business Survey Data - } \\
\text { Experiences from the Swedish Business Tendency } \\
\text { Surveys }\end{array}$ & 1993 \\
\hline $30 \mathrm{~b}$ & Bergström, Reinhold & $\begin{array}{l}\text { Quantitative Production Series Compared with } \\
\text { Qualiative Business Survey Series for Five Sectors of } \\
\text { the Swedish Manufacturing Industry }\end{array}$ & 1993 \\
\hline 31 & $\begin{array}{l}\text { Lin, Chien-Fu Jeff and } \\
\text { Timo Teräsvirta }\end{array}$ & $\begin{array}{l}\text { Testing the Constancy of Regression Parameters } \\
\text { Against Continous Change }\end{array}$ & 1993 \\
\hline 32 & $\begin{array}{l}\text { Markowski, } \\
\text { Aleksander and } \\
\text { Parameswar } \\
\text { Nandakumar }\end{array}$ & $\begin{array}{l}\text { A Long-Run Equilibrium Model for Sweden. The } \\
\text { Theory Behind the Long-Run Solution to the } \\
\text { Econometric Model KOSMOS }\end{array}$ & 1993 \\
\hline 33 & $\begin{array}{l}\text { Markowski, } \\
\text { Aleksander and Tony } \\
\text { Persson }\end{array}$ & $\begin{array}{l}\text { Capital Rental Cost and the Adjustment for the } \\
\text { Effects of the Investment Fund System in the } \\
\text { Econometric Model Kosmos }\end{array}$ & 1993 \\
\hline 34 & $\begin{array}{l}\text { Kanis, Alfred and } \\
\text { Bharat Barot }\end{array}$ & On Determinants of Private Consumption in Sweden & 1993 \\
\hline 35 & $\begin{array}{l}\text { Kääntä, Pekka and } \\
\text { Christer Tallbom }\end{array}$ & $\begin{array}{l}\text { Using Business Survey Data for Forecasting Swedish } \\
\text { Quantitative Business Cycle Varable. A Kalman Filter } \\
\text { Approach }\end{array}$ & 1993 \\
\hline 36 & $\begin{array}{l}\text { Ohlsson, Henry and } \\
\text { Anders Vredin }\end{array}$ & $\begin{array}{l}\text { Political Cycles and Cyclical Policies. A New Test } \\
\text { Approach Using Fiscal Forecasts }\end{array}$ & 1993 \\
\hline
\end{tabular}




\begin{tabular}{|c|c|c|c|}
\hline 37 & $\begin{array}{l}\text { Markowski, } \\
\text { Aleksander and Lars } \\
\text { Ernsäter }\end{array}$ & $\begin{array}{l}\text { The Supply Side in the Econometric Model } \\
\text { KOSMOS }\end{array}$ & 1994 \\
\hline 38 & $\begin{array}{l}\text { Gustafsson, Claes- } \\
\text { Håkan }\end{array}$ & $\begin{array}{l}\text { On the Consistency of Data on Production, } \\
\text { Deliveries, and Inventories in the Swedish } \\
\text { Manufacturing Industry }\end{array}$ & 1994 \\
\hline 39 & $\begin{array}{l}\text { Rahiala, Markku and } \\
\text { Tapani Kovalainen }\end{array}$ & $\begin{array}{l}\text { Modelling Wages Subject to Both Contracted } \\
\text { Increments and Drift by Means of a Simultaneous- } \\
\text { Equations Model with Non-Standard Error Structure }\end{array}$ & 1994 \\
\hline 40 & $\begin{array}{l}\text { Öller, Lars-Erik and } \\
\text { Christer Tallbom }\end{array}$ & $\begin{array}{l}\text { Hybrid Indicators for the Swedish Economy Based on } \\
\text { Noisy Statistical Data and the Business Tendency } \\
\text { Survey }\end{array}$ & 1994 \\
\hline 41 & Östblom, Göran & $\begin{array}{l}\text { A Converging Triangularization Algorithm and the } \\
\text { Intertemporal Similarity of Production Structures }\end{array}$ & 1994 \\
\hline $42 \mathrm{a}$ & $\begin{array}{l}\text { Markowski, } \\
\text { Aleksander }\end{array}$ & $\begin{array}{l}\text { Labour Supply, Hours Worked and Unemployment in } \\
\text { the Econometric Model KOSMOS }\end{array}$ & 1994 \\
\hline $42 \mathrm{~b}$ & $\begin{array}{l}\text { Markowski, } \\
\text { Aleksander }\end{array}$ & $\begin{array}{l}\text { Wage Rate Determination in the Econometric Model } \\
\text { KOSMOS }\end{array}$ & 1994 \\
\hline 43 & $\begin{array}{l}\text { Ahlroth, Sofia, Anders } \\
\text { Björklund and Anders } \\
\text { Forslund }\end{array}$ & The Output of the Swedish Education Sector & 1994 \\
\hline $44 \mathrm{a}$ & $\begin{array}{l}\text { Markowski, } \\
\text { Aleksander }\end{array}$ & $\begin{array}{l}\text { Private Consumption Expenditure in the Econometric } \\
\text { Model KOSMOS }\end{array}$ & 1994 \\
\hline $44 \mathrm{~b}$ & $\begin{array}{l}\text { Markowski, } \\
\text { Aleksander }\end{array}$ & $\begin{array}{l}\text { The Input-Output Core: Determination of Inventory } \\
\text { Investment and Other Business Output in the } \\
\text { Econometric Model KOSMOS }\end{array}$ & 1994 \\
\hline 45 & Bergström, Reinhold & $\begin{array}{l}\text { The Accuracy of the Swedish National Budget } \\
\text { Forecasts 1955-92 }\end{array}$ & 1995 \\
\hline 46 & Sjöö, Boo & $\begin{array}{l}\text { Dynamic Adjustment and Long-Run Economic } \\
\text { Stability }\end{array}$ & 1995 \\
\hline $47 \mathrm{a}$ & $\begin{array}{l}\text { Markowski, } \\
\text { Aleksander }\end{array}$ & $\begin{array}{l}\text { Determination of the Effective Exchange Rate in the } \\
\text { Econometric Model KOSMOS }\end{array}$ & 1995 \\
\hline $47 \mathrm{~b}$ & $\begin{array}{l}\text { Markowski, } \\
\text { Aleksander }\end{array}$ & $\begin{array}{l}\text { Interest Rate Determination in the Econometric } \\
\text { Model KOSMOS }\end{array}$ & 1995 \\
\hline 48 & Barot, Bharat & $\begin{array}{l}\text { Estimating the Effects of Wealth, Interest Rates and } \\
\text { Unemployment on Private Consumption in Sweden }\end{array}$ & 1995 \\
\hline 49 & Lundvik, Petter & Generational Accounting in a Small Open Economy & 1996 \\
\hline 50 & $\begin{array}{l}\text { Eriksson, Kimmo, } \\
\text { Johan Karlander and } \\
\text { Lars-Erik Öller }\end{array}$ & Hierarchical Assignments: Stability and Fairness & 1996 \\
\hline 51 & Url, Thomas & Internationalists, Regionalists, or Eurocentrists & 1996 \\
\hline 52 & Ruist, Erik & Temporal Aggregation of an Econometric Equation & 1996 \\
\hline 53 & $\begin{array}{l}\text { Markowski, } \\
\text { Aleksander }\end{array}$ & $\begin{array}{l}\text { The Financial Block in the Econometric Model } \\
\text { KOSMOS }\end{array}$ & 1996 \\
\hline
\end{tabular}




\begin{tabular}{|c|c|c|c|}
\hline 54 & Östblom, Göran & $\begin{array}{l}\text { Emissions to the Air and the Allocation of GDP: } \\
\text { Medium Term Projections for Sweden. In Conflict } \\
\text { with the Goals of } \mathrm{SO}_{2}, \mathrm{SO}_{2} \text { and NOX Emissions for } \\
\text { Year } 2000\end{array}$ & 1996 \\
\hline 55 & $\begin{array}{l}\text { Koskinen, Lasse, } \\
\text { Aleksander } \\
\text { Markowski, } \\
\text { Parameswar } \\
\text { Nandakumar and } \\
\text { Lars-Erik Öller } \\
\end{array}$ & Three Seminar Papers on Output Gap & 1997 \\
\hline 56 & $\begin{array}{l}\text { Oke, Timothy and } \\
\text { Lars-Erik Öller }\end{array}$ & Testing for Short Memory in a VARMA Process & 1997 \\
\hline 57 & $\begin{array}{l}\text { Johansson, Anders } \\
\text { and Karl-Markus } \\
\text { Modén }\end{array}$ & Investment Plan Revisions and Share Price Volatility & 1997 \\
\hline 58 & Lyhagen, Johan & $\begin{array}{l}\text { The Effect of Precautionary Saving on Consumption } \\
\text { in Sweden }\end{array}$ & 1998 \\
\hline 59 & $\begin{array}{l}\text { Koskinen, Lasse and } \\
\text { Lars-Erik Öller }\end{array}$ & $\begin{array}{l}\text { A Hidden Markov Model as a Dynamic Bayesian } \\
\text { Classifier, with an Application to Forecasting } \\
\text { Business-Cycle Turning Points }\end{array}$ & 1998 \\
\hline 60 & $\begin{array}{l}\text { Kragh, Börje and } \\
\text { Aleksander Markowski }\end{array}$ & $\begin{array}{l}\text { Kofi - a Macromodel of the Swedish Financial } \\
\text { Markets }\end{array}$ & 1998 \\
\hline 61 & $\begin{array}{l}\text { Gajda, Jan B. and } \\
\text { Aleksander Markowski }\end{array}$ & $\begin{array}{l}\text { Model Evaluation Using Stochastic Simulations: The } \\
\text { Case of the Econometric Model KOSMOS }\end{array}$ & 1998 \\
\hline 62 & Johansson, Kerstin & Exports in the Econometric Model KOSMOS & 1998 \\
\hline 63 & Johansson, Kerstin & $\begin{array}{l}\text { Permanent Shocks and Spillovers: A Sectoral } \\
\text { Approach Using a Structural VAR }\end{array}$ & 1998 \\
\hline 64 & $\begin{array}{l}\text { Öller, Lars-Erik and } \\
\text { Bharat Barot }\end{array}$ & Comparing the Accuracy of European GDP Forecasts & 1999 \\
\hline 65 & $\begin{array}{l}\text { Huhtala, Anni and } \\
\text { Eva Samakovlis }\end{array}$ & $\begin{array}{l}\text { Does International Harmonization of Environmental } \\
\text { Policy Instruments Make Economic Sense? The Case } \\
\text { of Paper Recycling in Europe }\end{array}$ & 1999 \\
\hline 66 & Nilsson, Charlotte & $\begin{array}{l}\text { A Unilateral Versus a Multilateral Carbon Dioxide } \\
\text { Tax - A Numerical Analysis With The European } \\
\text { Model GEM-E3 }\end{array}$ & 1999 \\
\hline 67 & $\begin{array}{l}\text { Braconier, Henrik and } \\
\text { Steinar Holden }\end{array}$ & $\begin{array}{l}\text { The Public Budget Balance - Fiscal Indicators and } \\
\text { Cyclical Sensitivity in the Nordic Countries }\end{array}$ & 1999 \\
\hline 68 & Nilsson, Kristian & $\begin{array}{l}\text { Alternative Measures of the Swedish Real Exchange } \\
\text { Rate }\end{array}$ & 1999 \\
\hline 69 & Östblom, Göran & $\begin{array}{l}\text { An Environmental Medium Term Economic Model - } \\
\text { EMEC }\end{array}$ & 1999 \\
\hline 70 & $\begin{array}{l}\text { Johnsson, Helena and } \\
\text { Peter Kaplan }\end{array}$ & $\begin{array}{l}\text { An Econometric Study of Private Consumption } \\
\text { Expenditure in Sweden }\end{array}$ & 1999 \\
\hline 71 & $\begin{array}{l}\text { Arai, Mahmood and } \\
\text { Fredrik Heyman }\end{array}$ & $\begin{array}{l}\text { Permanent and Temporary Labour: Job and Worker } \\
\text { Flows in Sweden 1989-1998 }\end{array}$ & 2000 \\
\hline
\end{tabular}




\begin{tabular}{|c|c|c|c|}
\hline 72 & $\begin{array}{l}\text { Öller, Lars-Erik and } \\
\text { Bharat Barot }\end{array}$ & $\begin{array}{l}\text { The Accuracy of European Growth and Inflation } \\
\text { Forecasts }\end{array}$ & 2000 \\
\hline 73 & Ahlroth, Sofia & $\begin{array}{l}\text { Correcting Net Domestic Product for Sulphur } \\
\text { Dioxide and Nitrogen Oxide Emissions: } \\
\text { Implementation of a Theoretical Model in Practice }\end{array}$ & 2000 \\
\hline 74 & $\begin{array}{l}\text { Andersson, Michael } \\
\text { K. And Mikael P. } \\
\text { Gredenhoff }\end{array}$ & $\begin{array}{l}\text { Improving Fractional Integration Tests with } \\
\text { Bootstrap Distribution }\end{array}$ & 2000 \\
\hline 75 & $\begin{array}{l}\text { Nilsson, Charlotte and } \\
\text { Anni Huhtala }\end{array}$ & $\begin{array}{l}\text { Is } \mathrm{CO}_{2} \text { Trading Always Beneficial? A CGE-Model } \\
\text { Analysis on Secondary Environmental Benefits }\end{array}$ & 2000 \\
\hline 76 & Skånberg, Kristian & $\begin{array}{l}\text { Constructing a Partially Environmentally Adjusted } \\
\text { Net Domestic Product for Sweden } 1993 \text { and } 1997\end{array}$ & 2001 \\
\hline 77 & $\begin{array}{l}\text { Huhtala, Anni, Annie } \\
\text { Toppinen and Mattias } \\
\text { Boman, }\end{array}$ & $\begin{array}{l}\text { An Environmental Accountant's Dilemma: Are } \\
\text { Stumpage Prices Reliable Indicators of Resource } \\
\text { Scarcity? }\end{array}$ & 2001 \\
\hline 78 & Nilsson, Kristian & $\begin{array}{l}\text { Do Fundamentals Explain the Behavior of the Real } \\
\text { Effective Exchange Rate? }\end{array}$ & 2002 \\
\hline 79 & Bharat, Barot & $\begin{array}{l}\text { Growth and Business Cycles for the Swedish } \\
\text { Economy }\end{array}$ & 2002 \\
\hline 80 & Bharat, Barot & $\begin{array}{l}\text { House Prices and Housing Investment in Sweden and } \\
\text { the United Kingdom. Econometric Analysis for the } \\
\text { Period 1970-1998 }\end{array}$ & 2002 \\
\hline 81 & Hjelm, Göran & $\begin{array}{l}\text { Simultaneous Determination of NAIRU, Output } \\
\text { Gaps and Structural Budget Balances: Swedish } \\
\text { Evidence }\end{array}$ & 2003 \\
\hline 82 & $\begin{array}{l}\text { Huhtala, Anni and } \\
\text { Eva Samalkovis }\end{array}$ & Green Accounting, Air Pollution and Health & 2003 \\
\hline 83 & Lindström, Tomas & $\begin{array}{l}\text { The Role of High-Tech Capital Formation for } \\
\text { Swedish Productivity Growth }\end{array}$ & 2003 \\
\hline 84 & $\begin{array}{l}\text { Hansson, Jesper, Per } \\
\text { Jansson and Mårten } \\
\text { Löf }\end{array}$ & $\begin{array}{l}\text { Business survey data: do they help in forecasting the } \\
\text { macro economy? }\end{array}$ & 2003 \\
\hline 85 & $\begin{array}{l}\text { Boman, Mattias, Anni } \\
\text { Huhtala, Charlotte } \\
\text { Nilsson, Sofia } \\
\text { Ahlroth, Göran } \\
\text { Bostedt, Leif Mattson } \\
\text { and Peichen Gong }\end{array}$ & $\begin{array}{l}\text { Applying the Contingent Valuation Method in } \\
\text { Resource Accounting: A Bold Proposal }\end{array}$ & \\
\hline 86 & Gren, Ing-Marie & Monetary Green Accounting and Ecosystem Services & 2003 \\
\hline 87 & $\begin{array}{l}\text { Samakovlis, Eva, Anni } \\
\text { Huhtala, Tom } \\
\text { Bellander and Magnus } \\
\text { Svartengren }\end{array}$ & $\begin{array}{l}\text { Air Quality and Morbidity: Concentration-response } \\
\text { Relationships for Sweden }\end{array}$ & 2004 \\
\hline 88 & $\begin{array}{l}\text { Alsterlind, Jan, Alek } \\
\text { Markowski and } \\
\text { Kristian Nilsson } \\
\end{array}$ & $\begin{array}{l}\text { Modelling the Foreign Sector in a Macroeconometric } \\
\text { Model of Sweden }\end{array}$ & 2004 \\
\hline 89 & Lindén, Johan & The Labor Market in KIMOD & 2004 \\
\hline
\end{tabular}




\begin{tabular}{|c|c|c|c|}
\hline 90 & $\begin{array}{l}\text { Henrik Braconier, } \\
\text { Tomas Forsfält }\end{array}$ & $\begin{array}{l}\text { A New Method for Constructing a Cyclically Adjusted } \\
\text { Budget Balance: the Case of Sweden }\end{array}$ & 2004 \\
\hline 91 & $\begin{array}{l}\text { Hansen, Sten and } \\
\text { Tomas Lindström }\end{array}$ & Is Rising Returns to Scale a Figment of Poor Data? & 2004 \\
\hline 92 & Hjelm, Göran & $\begin{array}{l}\text { When Are Fiscal Contractions Successful? Lessons for } \\
\text { Countries Within and Outside the EMU }\end{array}$ & 2004 \\
\hline 93 & $\begin{array}{l}\text { Östblom, Göran and } \\
\text { Samakovlis, Eva }\end{array}$ & $\begin{array}{l}\text { Costs of Climate Policy when Pollution Affects } \\
\text { Health and Labour Productivity. A General } \\
\text { Equilibrium Analysis Applied to Sweden }\end{array}$ & 2004 \\
\hline 94 & $\begin{array}{l}\text { Forslund Johanna, } \\
\text { Eva Samakovlis and } \\
\text { Maria Vredin } \\
\text { Johansson }\end{array}$ & $\begin{array}{l}\text { Matters Risk? The Allocation of Government } \\
\text { Subsidies for Remediation of Contaminated Sites } \\
\text { under the Local Investment Programme }\end{array}$ & 2006 \\
\hline 95 & $\begin{array}{l}\text { Erlandsson Mattias } \\
\text { and Alek Markowski }\end{array}$ & $\begin{array}{l}\text { The Effective Exchange Rate Index KIX - Theory } \\
\text { and Practice }\end{array}$ & 2006 \\
\hline 96 & $\begin{array}{l}\text { Östblom Göran and } \\
\text { Charlotte Berg }\end{array}$ & The EMEC model: Version 2.0 & 2006 \\
\hline 97 & $\begin{array}{l}\text { Hammar, Henrik, } \\
\text { Tommy Lundgren and } \\
\text { Magnus Sjöström }\end{array}$ & $\begin{array}{l}\text { The significance of transport costs in the Swedish } \\
\text { forest industry }\end{array}$ & 2006 \\
\hline 98 & Barot, Bharat & $\begin{array}{l}\text { Empirical Studies in Consumption, House Prices and } \\
\text { the Accuracy of European Growth and Inflation } \\
\text { Forecasts }\end{array}$ & 2006 \\
\hline 99 & Hjelm, Göran & $\begin{array}{l}\text { Kan arbetsmarknadens parter minska } \\
\text { jämviktsarbetslösheten? Teori och modellsimuleringar }\end{array}$ & 2006 \\
\hline 100 & $\begin{array}{l}\text { Bergvall, Anders, } \\
\text { Tomas Forsfält, } \\
\text { Göran Hjelm, } \\
\text { Jonny Nilsson and } \\
\text { Juhana Vartiainen }\end{array}$ & $\begin{array}{l}\text { KIMOD 1.0 Documentation of NIER's Dynamic } \\
\text { Macroeconomic General Equilibrium Model of the } \\
\text { Swedish Economy }\end{array}$ & 2007 \\
\hline 101 & Östblom, Göran & $\begin{array}{l}\text { Nitrogen and Sulphur Outcomes of a Carbon } \\
\text { Emissions Target Excluding Traded Allowances - } \\
\text { An Input-Output Analysis of the Swedish Case }\end{array}$ & 2007 \\
\hline 102 & $\begin{array}{l}\text { Hammar, Henrik and } \\
\text { Åsa Löfgren }\end{array}$ & $\begin{array}{l}\text { Explaining adoption of end of pipe solutions and } \\
\text { clean technologies - Determinants of firms' } \\
\text { investments for reducing emissions to air in four } \\
\text { sextors in Sweden }\end{array}$ & 2007 \\
\hline 103 & $\begin{array}{l}\text { Östblom, Göran and } \\
\text { Henrik Hammar }\end{array}$ & $\begin{array}{l}\text { Outcomes of a Swedish Kilometre Tax. An Analysis } \\
\text { of Economic Effects and Effects on NOx Emissions }\end{array}$ & 2007 \\
\hline 104 & $\begin{array}{l}\text { Forsfält, Tomas, } \\
\text { Johnny Nilsson and } \\
\text { Juhana Vartianinen }\end{array}$ & $\begin{array}{l}\text { Modellansatser i Konjunkturinstitutets } \\
\text { medelfristprognoser }\end{array}$ & 208 \\
\hline 105 & Samakovlis, Eva & $\begin{array}{l}\text { How are Green National Accounts Produced in } \\
\text { Practice? }\end{array}$ & 2008 \\
\hline
\end{tabular}




\begin{tabular}{|c|c|c|c|}
\hline 106 & $\begin{array}{l}\text { Alek Markowski, } \\
\text { Kristian Nilsson, } \\
\text { Marcus Widén }\end{array}$ & $\begin{array}{l}\text { Strukturell utveckling av arbetskostnad och priser i } \\
\text { den svenska ekonomin }\end{array}$ & 2011 \\
\hline 107 & $\begin{array}{l}\text { Forslund, Johanna, } \\
\text { Per Johansson, Eva } \\
\text { Samakovlis and Maria } \\
\text { Vredin Johansson }\end{array}$ & $\begin{array}{l}\text { Can we by time? Evaluation. Evaluation of the } \\
\text { government's directed grant to remediation in Sweden }\end{array}$ & 2009 \\
\hline 108 & $\begin{array}{l}\text { Forslund, Johanna } \\
\text { Eva Samakovlis, Maria } \\
\text { Vredin Johansson and } \\
\text { Lars Barregård }\end{array}$ & $\begin{array}{l}\text { Does Remediation Save Lives? } \\
\text { On the Cost of Cleaning Up } \\
\text { Arsenic-Contaminated } \\
\text { Sites in Sweden }\end{array}$ & 2009 \\
\hline 109 & $\begin{array}{l}\text { Sjöström, Magnus and } \\
\text { Göran Östblom }\end{array}$ & $\begin{array}{l}\text { Future Waste Scenarios for Sweden on the Basis of a } \\
\text { CGE-model }\end{array}$ & 2009 \\
\hline 110 & Österholm, Pär & $\begin{array}{l}\text { The Effect on the Swedish Real Economy of the } \\
\text { Financial Crisis }\end{array}$ & 2009 \\
\hline 111 & Forsfält, Tomas & $\begin{array}{l}\text { KIMOD } 2.0 \text { Documentation of changes in the model } \\
\text { from January } 2007 \text { to January } 2009\end{array}$ & 2009 \\
\hline 112 & Österholm, Pär & $\begin{array}{l}\text { Improving Unemployment Rate Forecasts Using } \\
\text { Survey Data }\end{array}$ & 2009 \\
\hline 113 & Österholm, Pär & $\begin{array}{l}\text { Unemployment and Labour-Force } \\
\text { Participation in Sweden }\end{array}$ & 2009 \\
\hline 114 & $\begin{array}{l}\text { Jonsson, Thomas and } \\
\text { Pär Österholm }\end{array}$ & $\begin{array}{l}\text { The Properties of Survey-Based } \\
\text { Inflation Expectations in Sweden }\end{array}$ & 2009 \\
\hline 115 & $\begin{array}{l}\text { Hjelm, Göran and } \\
\text { Kristian Jönsson }\end{array}$ & $\begin{array}{l}\text { In Search of a Method for Measuring the Output Gap } \\
\text { of the Swedish Economy }\end{array}$ & 2010 \\
\hline 116 & Vartiainen, Juhana & Interpreting Wage Bargaining Norms & 2010 \\
\hline 117 & $\begin{array}{l}\text { Mossfeldt, Marcus and } \\
\text { Pär Österholm }\end{array}$ & $\begin{array}{l}\text { The Persistent Labour-Market Effects of the Financial } \\
\text { Crisis }\end{array}$ & 2010 \\
\hline 118 & $\begin{array}{l}\text { Östblom, Göran, } \\
\text { Maria Ljunggren } \\
\text { Söderman and Magnus } \\
\text { Sjöström }\end{array}$ & $\begin{array}{l}\text { Analysing future solid waste generation - Soft linking } \\
\text { a model of waste management with a CGE-model for } \\
\text { Sweden }\end{array}$ & 2010 \\
\hline 119 & $\begin{array}{l}\text { Broberg, Thomas, } \\
\text { Per-Olov Marklund, } \\
\text { Eva Samakovlisa and } \\
\text { Henrik Hammar }\end{array}$ & $\begin{array}{l}\text { Does environmental leadership pay off for Swed-ish } \\
\text { industry? - Analyzing the effects of environ-mental } \\
\text { investments on efficiency }\end{array}$ & 2010 \\
\hline 120 & $\begin{array}{l}\text { Gustavsson, Magnus } \\
\text { and Pär Österholm }\end{array}$ & $\begin{array}{l}\text { Labor-Force Participation Rates and the } \\
\text { Informational Value of Unemployment Rates: } \\
\text { Evidence from Disaggregated US Data }\end{array}$ & 2010 \\
\hline 121 & $\begin{array}{l}\text { Jonsson, Thomas and } \\
\text { Pär österholm }\end{array}$ & $\begin{array}{l}\text { The Forecasting Properties of Survey-Based Wage- } \\
\text { Growth Expectations }\end{array}$ & 2010 \\
\hline 123 & $\begin{array}{l}\text { Broberg, Thomas, } \\
\text { Tomas Forsfält and } \\
\text { Göran Östblom }\end{array}$ & $\begin{array}{l}\text { The Excess Cost of Supplementary Constraints in } \\
\text { Climate Policy: The Case of Sweden's Energy } \\
\text { Intensity Target }\end{array}$ & 2011 \\
\hline
\end{tabular}




\begin{tabular}{|c|c|c|c|}
\hline 124 & $\begin{array}{l}\text { Patrik Baard, Henrik } \\
\text { Carlsen, Karin } \\
\text { Edvardsson Björnberg } \\
\text { and Maria Vredin } \\
\text { Johansson }\end{array}$ & $\begin{array}{l}\text { Scenarios and Sustainability. A Swedish Case Study of } \\
\text { Adaptation Tools for Local Decision-Makers }\end{array}$ & 2011 \\
\hline 125 & $\begin{array}{l}\text { Hansson, Sven Ove, } \\
\text { Karin Edvardsson } \\
\text { Björnberg and } \\
\text { Maria Vredin } \\
\text { Johansson }\end{array}$ & $\begin{array}{l}\text { Making Climate Policy Efficient } \\
\text { Implementing a Model for Environmental Policy } \\
\text { Efficiency }\end{array}$ & 2011 \\
\hline 126 & $\begin{array}{l}\text { Antipin, Jan-Erik, } \\
\text { Farid Jimmy } \\
\text { Boumediene and Pär } \\
\text { Österholm }\end{array}$ & $\begin{array}{l}\text { Forecasting Inflation Using Constant Gain Least } \\
\text { Squares }\end{array}$ & 2012 \\
\hline 127 & $\begin{array}{l}\text { Meredith Beechey, Pär } \\
\text { Österholm }\end{array}$ & $\begin{array}{l}\text { Policy Interest Rate Expectations in Sweden: A } \\
\text { Forecast Evaluation }\end{array}$ & 2012 \\
\hline 128 & $\begin{array}{l}\text { Meredith Beechey, Pär } \\
\text { Österholm }\end{array}$ & $\begin{array}{l}\text { Central Bank Forecasts of Policy Interest Rates: An } \\
\text { Evaluation of the First Years }\end{array}$ & 2013 \\
\hline 129 & $\begin{array}{l}\text { Jan-Erik Antipin, } \\
\text { Farid Jimmy } \\
\text { Boumediene, Pär } \\
\text { Österholm }\end{array}$ & $\begin{array}{l}\text { On the Usefulness of Constant Gain Least Squares } \\
\text { when Forecasting the Unemployment Rate }\end{array}$ & 2013 \\
\hline 130 & Pär Österholm & $\begin{array}{l}\text { Survey Data and Short-Term Forecasts of Swedish } \\
\text { GDP Growth }\end{array}$ & 2013 \\
\hline
\end{tabular}


National Institute of Economic Research, Kungsgatan 12-14, Box 3116, SE-103 62 Stockholm, Sweden Phone: +46 845359 00, Fax: +46 845359 80, E-mail: ki@konj.se, Website: www.konj.se

ISSN $1100-7818$ 